\section{Use of thoracic radiotherapy for extensive stage small-cell lung cancer: a phase 3 randomised controlled trial}

Slotman BJ, van Tinteren $\mathrm{H}$, Praag JO i wsp.

Lancet 2015; 385: 36-42

U większości chorych z postacią rozsianą drobnokomórkowego raka płuca, którzy otrzymali chemioterapię oraz profilaktyczne napromienianie mózgowia, stwierdza się przetrwałą chorobę w klatce piersiowej. Oceniono rolę napromieniania na obszar klatki piersiowej w tej grupie chorych.

Metody. Badanie III fazy z losowym doborem chorych przeprowadzono w 42 ośrodkach: 16 holenderskich, 22 brytyjskich, 3 norweskich i 1 belgijskim. Do badania włączano chorych na drobnokomórkowego raka płuca w stadium rozległym, w dobrym stanie sprawności (PS =0-2), którzy odpowiedzieli na chemioterapię. Chorych przydzielano losowo w stosunku 1:1 do chemioterapii z profilaktycznym napromienianiem mózgowia oraz radioterapią na obszar klatki piersiowej (30 Gy w 10 frakcjach) lub do wyłącznej chemioterapii z profilaktycznym napromienianiem mózgowia. Pierwotnym punktem końcowym był udział rocznych przeżyć w populacji leczonej zgodnie z intencją leczenia. Wtórnym punktem końcowym był czas do progresji.

Wyniki. Od 18 lutego 2009 roku do 21 grudnia 2012 roku do leczenia przydzielono losowo 498 chorych. 3 chorych wycofało zgodę. W grupie otrzymującej radioterapię na obszar klatki piersiowej było 247 chorych, a w grupie kontrolnej 248. Czas pomiędzy rozpoznaniem a przydziałem losowym wyniósł średnio 17 tygodni. Mediana czasu obserwacji wyniosła 24 miesiące. Udział całkowitych rocznych przeżyć nie różnił się znamiennie pomiędzy grupami: 33\% (95\% Cl 27-39\%) w grupie poddanej radioterapii w porównaniu z 28\% (95\% Cl 22-34\%) w grupie kontrolnej (współczynnik ryzyka [HR] 0,84, 95\% Cl 0,69-1,01; p=0,066). Udział całkowitych 2-letnich przeżyć w obu grupach wyniósł odpowiednio 13\% (95\% Cl 9-19) i do 3\% (95\% Cl 2-8; p = 0,004). Progresja występowała rzadziej w grupie chorych napromienianych na obszar klatki piersiowej (HR 0,73, 95\% Cl $0,61-0,87 ; p=0,001)$. Po 6 miesiącach czas do progresji wyniósł odpowiednio $24 \%$ (95\% Cl 19-30\%) w porównaniu z 7\% (95\% Cl 4-11\%; p = 0,001). Nie obserwowano nasilonych działań niepożądanych. Najczęściej występującymi działaniami ubocznymi w 3 . lub wyższym stopniu nasilenia były zmęczenie (11 vs 9\%) i duszność (3 vs 4\%).
Wnioski. U chorych z postacią rozsianą drobnokomórkowego raka płuca, którzy odpowiedzieli na chemioterapię, oprócz profilaktycznego napromieniania mózgowia należy rozważyć napromienianie na okolicę klatki piersiowej.

\section{Lenvatinib versus placebo in radioiodine- -refractory thyroid cancer}

Schlumberger M, Tahara M, Wirth LJ i wsp.

N Engl J Med 2015; 372: 621-630

W badaniach II fazy lenwatynib, doustny inhibitor receptorów VEGF 1-3, FGF 1-4, PDGFR $\alpha$, RET oraz KIT, wykazał aktywność u chorych na zróżnicowanego, opornego na radiojod, raka tarczycy.

Metody. Do wieloośrodkowego, podwójnie zaślepionego badania III fazy z losowym doborem chorych włączono chorych z progresją w przebiegu opornego na radiojod, raka tarczycy. 261 chorych przydzielono losowo do lenwatynibu (w dawce dobowej 24 mg w 28-dniowych cyklach), a 131 chorych do placebo. Chorzy otrzymujący placebo po progresji mogli otrzymywać lenwatynib. Pierwotnym punktem końcowym był czas do progresji. Wtórnymi punktami końcowymi były: udział odpowiedzi, czas całkowitego przeżycia i bezpieczeństwo.

Wyniki. Mediana czasu do progresji w grupie otrzymującej lenwatynib wyniosła 18,3 miesiąca, a w grupie otrzymującej placebo 3,6 miesiąca (współczynnik ryzyka progresji lub zgonu 0,21; 99\% przedział ufności 0,14 do 0,31; $<<0,001$ ). Wydłużenie czasu do progresji obserwowano we wszystkich analizowanych podgrupach chorych. Udział odpowiedzi wyniósł 64,8\% w grupie otrzymującej lenwatynib (4 odpowiedzi całkowite oraz 165 odpowiedzi częściowych) i 1,5\% w grupie placebo $(p<0,001)$. Nie osiągnięto mediany całkowitego czasu przeżycia w żadnej z grup. Działaniami niepożądanymi związanymi z leczeniem, które wystąpiły u ponad $40 \%$ chorych otrzymujących lenwatynib, były: nadciśnienie tętnicze $(67,8 \%)$, biegunka $(59,4 \%)$, zmęczenie lub astenia (59,0\%), utrata apetytu (50,2\%), ubytek masy ciała $(46,4 \%)$ i nudności $(41,0 \%) .37$ chorych otrzymujących lenwatynib $(14,2 \%)$ oraz 3 chorych otrzymujących placebo $(2,3 \%)$ zrezygnowało z leczenia z powodu działań niepożądanych. Uznano, że 6 spośród 20 zgonów, które wystąpiły w grupie chorych otrzymujących lenwatynib, było związanych z badanym lekiem. 
Wnioski. W grupie chorych na opornego na radiojod raka tarczycy zastosowanie lenwatynibu wiązało się ze znamiennym wydłużeniem czasu do progresji i wyższym udziałem odpowiedzi w porównaniu z placebo. U chorych otrzymujących lenwatynib obserwowano więcej działań niepożądanych.

\section{Whole-breast irradiation with or without a boost for patients treated with breast-conserving surgery for early breast cancer: 20-year follow-up of a randomised phase 3 trial}

Bartelink $\mathrm{H}$, Maingon P, Poortmans P i wsp.

Lancet Oncol 2015; 16: 47-56

Od czasu wprowadzenia leczenia oszczędzającego pierś stosowano różne schematy dawkowania uzupełniającej radioterapii. W badaniu III fazy z losowym doborem chorych porównano wpływ podwyższenia dawki o 16 Gy w loży po guzie (boost) na czas całkowitego przeżycia, kontrolę miejscową i zwłóknienie piersi u chorych na raka piersi w I-II stopniu zaawansowania poddanych zabiegowi oszczędzającemu pierś w porównaniu z chorymi, u których nie podwyższano dawki w obszarze operowanym. Przedstawiono wyniki po 20 latach obserwacji.

Metody. Chore po mikroskopowo radykalnym wycięciu naciekającego raka piersi, po uzupełniającej radioterapii na obszar całej piersi (50 Gy/5 tygodni), przydzielano losowo (1:1) do 16 Gy boostu lub do wyłącznej radioterapii na całą pierś z minimizacją względem wieku, stanu menopauzalnego, obecności rozległego komponentu DCIS, wielkości guza, stanu węzłów chłonnych i ośrodka. Pierwotnym punktem końcowym był całkowity czas przeżycia w populacji zgodnej z intencją leczenia.

Wyniki. Od 24 maja 1989 roku do 25 czerwca 1996 roku 2657 chorych przydzielono losowo do wyłącznej radioterapii na obszar całej piersi, a 2661 chorych do dodatkowej dawki boostu. Mediana czasu obserwacji wyniosła 17,2 roku (IQR 13,0-19,0). Udział 20-letnich całkowitych przeżyć wyniósł 59,7\% (99\% Cl 56,3-63,0) w grupie, która otrzymała boost, w porównaniu z 61,1\% (57,6-64,3) w grupie, która nie otrzymała boostu, współczynnik ryzyka (HR) 1,05 (99\% Cl $0,92-1,19, p=0,323)$. Wznowa choroby w operowanej piersi była pierwszym obserwowanym niepowodzeniem leczenia u 354 chorych (13\%) w grupie, która nie otrzymała boostu, w porównaniu z 237 chorymi (9\%), które otrzymały boost, HR 0,65 (99\% Cl 0,52-0,81, p<0,0001). 20-letnie skumulowane ryzyko wystąpienia nawrotu w leczonej piersi wyniosło $16,4 \%$ (99\% Cl 14,1-18,8) w grupie chorych, które nie otrzymały boostu, w porównaniu z 12,0\% $(9,8-14,4)$ w grupie chorych, które otrzymały boost. Mastektomię jako pierwsze leczenie ratunkowe wznowy miejscowej przeprowadzono u 279 (79\%) spośród 354 chorych, które nie otrzymały boostu, w porównaniu ze 178 (75\%) spośród 237 chorych, które otrzymały boost. 20-letnia skumulowana częstość nasilonego włóknienia piersi wyniosła 1,8\% (99\% Cl 1,1-2,5) w grupie chorych, które nie otrzymały boostu, w porównaniu z 5,2\% $(99 \%$ Cl 3,9-6,4) w grupie chorych, które otrzymały boost ( $\mathrm{p}<0,0001)$.

Wnioski. Zastosowanie boostu po napromienianiu całej piersi nie wpływa na czas całkowitego przeżycia, ale może poprawić kontrolę miejscową z potencjalnie największym zyskiem w grupie młodych chorych, przy zwiększonym ryzyku umiarkowanego i nasilonego zwłóknienia piersi. U większości chorych powyżej 60. roku życia można odstąpić od podawania boostu.

\section{Tamoxifen for prevention of breast cancer: extended long-term follow-up of the IBIS-I breast cancer prevention trial}

Cuzick J, Sestak I, Cawthorn S i wsp.

Lancet Oncol 2015; 16: 67-75

W 4 dotychczas opublikowanych badaniach klinicznych z losowym doborem chorych wykazano, że zastosowanie tamoksyfenu u zdrowych kobiet z podwyższonym ryzykiem zachorowania na raka piersi może prowadzić do zmniejszenia ryzyka zachorowania na ten nowotwór w pierwszych 10 latach trwania obserwacji. Przedstawiono późne wyniki podwójnie zaślepionego badania IBIS-I.

Metody. W badaniu IBIS-I kobiety w okresie przed-i pomenopauzalnym, w wieku od 35 do 70 lat, z grupy podwyższonego ryzyka zachorowania na raka piersi, przydzielano losowo (1:1) do tamoksyfenu (20 mg/d doustnie) lub placebo, stosowanych przez okres 5 lat. Uczestniczki przydzielano do grup według schematu blokowej randomizacji (liczebność permutowanego bloku 6 lub 10). Wykorzystano centralną randomizację oraz kodowanie dostaw leku w celu maskowania uczestniczek i badaczy względem przydziału do leczenia. Pierwotnym punktem końcowym było zachorowanie na raka piersi (inwazyjnego lub DCIS), oceniane w populacji zgodnej z intencją leczenia. Zachorowalność na raka piersi oraz umieralność oceniano przy użyciu modelu proporcjonalnego ryzyka Coxa. Zamknięto rekrutację do badania oraz zakończono aktywną fazę leczenia, ale uczestniczki podlegają dalszej obserwacji.

Wyniki. Od 14 kwietnia 1992 roku do 30 marca 2001 roku w 8 krajach włączono do badania 7154 kobiety: 3579 do tamoksyfenu i 3575 do placebo. Po medianie czasu obserwacji, która wyniosła 16,0 lat (IQR 14,1-17,6), odnotowano 601 zachorowań na raka piersi $(251$ [7,0\%] spośród 3579 otrzymujących tamoksyfen vs 350 [9,8\%] spośród 3575 otrzymujących placebo; współczynnik ryzyka [HR] 0,71 [95\% Cl 0,60-0,83], p < 0,0001). Ryzyko zachorowania na raka piersi było podobne w ciągu 10 lat obserwacji 
(226 spośród 3575 kobiet otrzymujących placebo [6,3\%] vs 163 spośród 3579 kobiet otrzymujących tamoksyfen [4,6\%]; HR 0,72 [95\% Cl 0,59-0,88], $p=0,001$ ) i po 10 latach (odpowiednio 124 spośród 3295 kobiet [3,8\%] vs 88 spośród 3343 [2,6\%]; HR 0,69 [0,53-0,91], p = 0,009). Najistotniejsze zmniejszenie ryzyka dotyczyło naciekającego raka piersi $z$ dodatnim receptorem estrogenowym (HR 0,66 [95\% Cl $0,54-0,81], p<0,0001)$ oraz DCIS $(0,65[0,43-1,00], p=0,05)$, nie zaobserwowano natomiast wpływu na ryzyko zachorowania na naciekającego raka piersi bez receptora estrogenowego (HR 1,05 [95\% Cl 0,71-1,57], p=0,8).

Wnioski. Ochronne działanie tamoksyfenu utrzymuje się długo po zakończeniu jego stosowania, co znacząco poprawia współczynnik korzyść/działania niepożądane w zapobieganiu rakowi piersi.

\section{A 9-valent HPV vaccine against infection and intraepithelial neoplasia in women}

Joura E, Giuliano A, Iversen OE

N Engl J Med 2015; 372: 711-723

Badana 9-walentna wirusopodobna szczepionka przeciwko wirusowi brodawczaka ludzkiego obejmuje typy wirusa zawarte w szczepionce 4-walentnej (HPV 6, 11, 16, i 18) oraz 5 dodatkowych typów onkogennych (31, 33, 45, 52 i 58). Przedstawiono ocenę skuteczności i immunogenności 9-walentnej szczepionki przeciwko HPV w grupie kobiet w wieku od 16 do 26 lat.

Metody. Do międzynarodowego, podwójnie zaślepionego badania fazy Ilb-III z losowym doborem chorych włączono 14215 kobiet. Uczestniczki otrzymywały 9-walentną lub 4-walentną szczepionkę w serii 3 domięśniowych iniekcji (dzień 1., a następnie po 2 i 6 miesiącach). Oceniano odpowiedź humoralną przeciwciał w osoczu. Pobierano wycinki z warg sromowych, sromu, krocza, okolicy okołoodbytniczej, kanału oraz tarczy szyjki macicy i oznaczano w nich HPV-DNA. Dodatkowo wykonywano regularnie testy cytologiczne (test Papanicolau). Wykonywano testy na obecność HPV w materiale $z$ biopsji oraz materiale pooperacyjnym (np. po elektroresekcji lub konizacji).

Wyniki. Wskaźnik chorób szyjki macicy, sromu lub pochwy o wysokim stopniu, niezależnie od typu HPV (np. choroba wywołana przez typy HPV uwzględnione w szczepionce 9-walentneji te nieuwzględnione) w zmodyfikowanej populacji analizowanej zgodnie z intencją leczenia (obejmującej uczestniczki z infekcją lub bez rozpowszechnionej infekcji lub choroby) wyniósł 14,0 na 1000 osobolat w obu grupach poddanych szczepieniu. Wskaźnik chorób szyjki macicy, sromu lub pochwy o wysokim stopniu wywołanych przez HPV 31, 33, 45, 52 i 58 w populacji oceniającej skuteczność protokołu (podatna populacja) wyniósł 0,1 na 1000 osobolat w grupie, która otrzymała szczepionkę 9-walentną i 1,6 na
1000 osobolat w grupie, która otrzymała szczepionkę 4-walentną (skuteczność szczepionki 9-walentnej 96,7\%; 95\% przedział ufności, 80,9-99,8). Odpowiedź humoralna przeciwko HPV-6, 11, 16 i 18 nie była słabsza od wywoływanej przez szczepionkę 4-walentną. Działania niepożądane obserwowane w miejscu iniekcji występowały częściej w grupie uczestniczek, które otrzymały szczepionkę 9-walentną. Wnioski. Zastosowanie 9-walentnej szczepionki w podatnej populacji zapobiegło infekcjom i chorobom wywołanym przez wirusa HPV 31, 33, 45, 52 i 58 oraz wywołało odpowiedź humoralną przeciwko HPV 6, 11, 16 i 18, równoważną odpowiedzi na szczepionkę 4-walentną. Zastosowanie 9-walentnej szczepionki nie zapobiegło infekcjom i chorobom wywołanym przez typy HPV nie uwzględnione w spektrum szczepionki.

\section{Pertuzumab, trastuzumab, and docetaxel in HER2-positive metastatic breast cancer \\ Swain S, Baselga J, Kim SB i wsp. \\ NEngl J Med 2015; 372: 724-734}

Czas do progresji chorych na uogólnionego raka piersi z dodatnim receptorem HER2 wydłużył się znamiennie po zastosowaniu w pierwszej linii pertuzumabu, trastuzumbu i docetakselu w porównaniu z placebo, trastuzumabem i docetakselem. W częściowej analizie pertuzumab znamiennie wydłużył czas całkowitego przeżycia, nie osiągnięto natomiast mediany. Przedstawiono ostateczne dane dotyczące czasu całkowitego przeżycia po medianie obserwacji 50 miesięcy.

Metody. Chore na uogólnionego raka piersi, które nie otrzymały wcześniej chemioterapii lub leczenia anty-HER2, przydzielano losowo do leczenia skojarzonego z pertuzumabem lub leczenia skojarzonego z placebo. Wtórnymi punktami końcowymi były: czas całkowitego przeżycia, czas do progresji oceniany przez badacza, niezależnie oceniany czas trwania odpowiedzi oraz bezpieczeństwo.

Wyniki. Mediana czasu całkowitego przeżycia wyniosła 56,5 miesiąca (95\% przedział ufności [Cl], 49,3 do nieosiągniętego) w grupie otrzymującej leczenie skojarzone z pertuzumabem w porównaniu z 40,8 miesiąca $(95 \% \mathrm{Cl}$, $35,8$ do 48,3$)$ w grupie otrzymującej leczenie skojarzone z placebo (współczynnik 95\% Cl, 0,56 do 0,84; p < 0,001). Mediana czasu do progresji ocenionego przez badacza była o 6,3 miesiąca dłuższa w grupie otrzymującej pertuzumab (współczynnik ryzyka 0,68; 95\% Cl 0,58 do 0,80). Pertuzumab wydłużył medianę trwania odpowiedzi o 7,7 miesiąca. W obu grupach większość działań niepożądanych związana była z podawaniem docetakselu, z zachowaniem długotrwałego bezpieczeństwa sercowo-naczyniowego.

Wnioski. W grupie chorych na uogólnionego raka piersi z obecnością receptora HER2 skojarzenie trastuzumabu i do- 
cetakselu z pertuzumabem, w porównaniu ze skojarzeniem z placebo, znamiennie wydłużyło medianę całkowitego przeżycia do 56,5 miesiąca, ostatecznie potwierdzając skuteczność tego połączenia leków.

\section{Adjuvant chemotherapy after preoperative (chemo)radiotherapy and surgery for patients with rectal cancer: a systematic review and meta-analysis of individual patient data}

Breugom A, Swets M, Bosset JF i wsp.

Lanet Oncol 2015; 16: 200-207

Rola uzupełniającej chemioterapii u chorych na raka odbytnicy poddanych przedoperacyjnej (chemio)radioterapii i zabiegowi operacyjnemu nie jest dokładnie określona. Przeprowadzono metaanalizę indywidualnych danych chorych w celu porównania skuteczności uzupełniającej chemioterapii z obserwacją w populacji chorych na raka odbytnicy.

Metody. Z zasobów PubMed, Medline, Embase, Web of Science, the Cochrane Library, CENTRAL i abstraktów konferencyjnych wybrano europejskie badania kliniczne III fazy z losowym doborem chorych, porównujące obserwację z uzupełniającą chemioterapią zastosowaną po przedoperacyjnej (chemio)radioterapii i zabiegu operacyjnym w grupie chorych na miejscowo zaawansowanego raka odbytnicy. Pierwotnym punktem końcowym był czas całkowitego przeżycia.

Wyniki. Oceniono 4 badania kliniczne z udziałem 1196 chorych na raka odbytnicy zlokalizowanego w odległości $\leq 15 \mathrm{~cm}$ od brzegu odbytu, w II-III stopniu zaawansowania klinicznego, których poddano radykalnej (R0) niskiej przedniej resekcji odbytnicy lub amputacji brzuszno-kroczowej. Nie wykazano znamiennej różnicy w czasie całkowitego przeżycia pomiędzy analizowanymi grupami (współczynnik ryzyka [HR] 0,97, 95\% Cl 0,81-1,17; p = 0,775); nie wykazano także znamiennych różnic w czasie całkowitego przeżycia w wyodrębnionych podgrupach. Zastosowanie uzupełniającej chemioterapii nie wydłużyło znamiennie czasu do nawrotu (HR 0,91,95\% Cl 0,77-1,07; p=0,230) i nie zmniejszyło ryzyka przerzutów odległych $(0,94,0,78-1,14 ; p=0,523)$ w porównaniu z obserwacją. W analizie podgrup wykazano wydłużenie czasu do nawrotu $(0,59,0,40-0,85 ; p=0,005$, $\left.\mathrm{p}_{\text {interakcji }}=0,107\right)$ i mniej przerzutów odległych $(0,61,0,40-0,94$; $\left.\mathrm{p}=0,025, \mathrm{p}_{\text {interakcji }}=0,126\right)$ w podgrupie chorych $\mathrm{z}$ guzem zlokalizowanym w odległości 10-15 cm od brzegu odbytu, którzy otrzymywali uzupełniającą chemioterapię w porównaniu z chorymi poddawanymi obserwacji.

Wnioski. Zastosowanie uzupełniającej chemioterapii zawierającej fluorouracyl nie wydłużyło czasu całkowitego przeżycia, czasu do nawrotu i nie zmniejszyło udziału przerzutów odległych. Korzyść z zastosowania uzupełniającej chemioterapii (w zakresie czasu do nawrotu i udziału przerzutów odległych) może dotyczyć chorych z guzem odbytnicy zlokalizowanym 10-15 cm od brzegu odbytu. Potrzeba dalszych badań nad przedoperacyjnym i pooperacyjnym leczeniem w tej podgrupie chorych.

\section{PD-1 blockade with nivolumab in relapsed or refractory Hodgkin's lymphoma}

Ansell SM, Lesokhin AM, Borrello i wsp.

NEngl J Med 2015; 372: 311-319

Przedkliniczne badania sugerują, że komórki Reed-Sternberga wykorzystują ścieżkę programowanej śmierci 1 (programmed death 1 - PD-1) do unikania wykrycia przez system immunologiczny. W klasycznym chłoniaku Hodgkina zaburzenia w chromosomie 9p24.1 zwiększają dostępność ligandów PD-1, PD-L1 i PD-L2 oraz promują ich indukcję przez kinazę Janusa (JAK) oraz transduktor sygnału i aktywator transkrypcji (STAT). Postawiono hipotezę, że niwolumab, przeciwciało blokujące PD-1, może zahamować unikanie przez guz układu immunologicznego u chorych na opornego lub nawrotowego chłoniaka Hodgkina.

Metody. 23 chorych na nawrotowego lub opornego chłoniaka Hodgkina po wielu liniach leczenia otrzymało niwolumab (w dawce $3 \mathrm{mg} / \mathrm{kg}$ ) co 2 tygodnie do czasu całkowitej odpowiedzi, progresji lub nadmiernej toksyczności. Celem badania była ocena bezpieczeństwa, skuteczności oraz zbadanie loci PDL1 i PDL2 (nazywanych odpowiednio CD274 i PDCD1LG2), a także ekspresji białek PD-L1 i PD-L2.

Wyniki. Spośród 23 chorych 78\% miało nawrót po autologicznym przeszczepieniu komórek macierzystych i 78\% miało nawrót po leczeniu brentuksymabem wendotinem. Związane z leczeniem niepożądane działania jakiegokolwiek stopnia i 3. stopnia wystąpiły odpowiednio u 78\% i $22 \%$ chorych. Obiektywne odpowiedzi uzyskano u 20 chorych (87\%), w tym $17 \%$ całkowitych odpowiedzi oraz $70 \%$ częściowych odpowiedzi; u pozostałych 3 chorych (13\%) doszło do stabilizacji choroby. Udział przeżyć bez progresji po 24 tygodniach wyniósł 86\%; 11 chorych kontynuowało udział w badaniu. Powodami zakończenia leczenia były: przeszczepienie krwiotwórczych komórek macierzystych (u 6 chorych), progresja (u 4 chorych) oraz toksyczność leczenia (u 2 chorych). Analiza materiału pobranego z guza przed leczeniem od 10 chorych wykazała zwiększenie liczby kopii genów PDL1 i PDL2 oraz zwiększoną ekspresję tych ligandów. Komórki Reed-Sternberga były dodatnie na fosforylowany STAT3, znak aktywnego przekazywania sygnału komórkowego poprzez JAK-STAT.

Wnioski. Niwolumab był skuteczny w leczeniu chorych na nawrotowego lub opornego chłoniaka Hodgkina, przy akceptowalnej toksyczności. 


\section{Nivolumab in previously untreated melanoma without BRAF mutation}

Robert C, Long GV, Brady B i wsp.

NEngl J Med 2015; 372: 320-330

Niwolumab pozwalał na uzyskanie wyższego udziału obiektywnych odpowiedzi w badaniu III fazy u chorych na rozsianego czerniaka opornego na ipilimumab w porównaniu z chemioterapią. Nie oceniano dotychczas niwolumabu w badaniu III fazy u wcześniej nieleczonych chorych na zaawansowanego czerniaka.

Metody. 418 wcześniej nieleczonych chorych na rozsianego czerniaka bez mutacji BRAF przydzielono losowo do leczenia niwolumabem (w dawce $3 \mathrm{mg} / \mathrm{kg}$ co 2 tygodnie z placebo zastępującym dakarbazynę co 3 tygodnie) lub dakarbazyny (w dawce 1000 mg/m² co 3 tygodnie z placebo zastępującym niwolumab co 2 tygodnie). Pierwotnym punktem końcowej oceny był czas całkowitego przeżycia.

Wyniki. Po roku udział całkowitych przeżyć wyniósł 72,9\% (95\% przedział ufności [Cl] 65,5 do 78,9) w grupie leczonej niwolumabem w porównaniu z 42,1\% (95\% Cl 33,0 do 50,9) w grupie leczonej dakarbazyną (współczynnik ryzyka zgonu 0,42; 99,79\% Cl 0,25 do 0,73; p < 0,001). Mediana czasu do progresji wyniosła 5,1 miesiąca w grupie leczonej niwolumabem w porównaniu z 2,2 miesiąca w grupie leczonej dakarbazyną (współczynnik ryzyka zgonu lub progresji 0,43; 95\% Cl 0,34 do 0,56; p < 0,001). Udział obiektywnych odpowiedzi wyniósł 40,0\% (95\% Cl 33,3 do 47,0\% w grupie leczonej niwolumabem w porównaniu z 13,9\% $(95 \% \mathrm{Cl}$ 9,5 do 19,4\%) w grupie leczonej dakarbazyną (iloraz szans 4,06; $p<0,001)$. Korzyść w przeżyciu po zastosowaniu niwolumabu w porównaniu z dakarbazyną występowała we wszystkich wcześniej określonych podgrupach, w tym w podgrupach zależnych od stanu liganda dla 1. receptora programowanej śmierci (PD-L1). Częstymi działaniami niepożądanymi po zastosowaniu niwolumabu były zmęczenie, świąd i nudności. Działania niepożądane 3. i 4. stopnia związane z lekiem wystąpiły u 11,7\% chorych leczonych niwolumabem oraz u 17,6\% wśród leczonych dakarbazyną. Wnioski. Niwolumab był związany ze znamiennym wydłużeniem czasem całkowitego przeżycia oraz czasem do progresji w porównaniu z dakarbazyną wśród nieleczonych chorych na rozsianego czerniaka bez mutacji BRAF.

\section{Adjuvant paclitaxel and trastuzumab for node-negative, HER2-positive breast cancer}

Tolaney SM, Barry WT, Dang CT i wsp.

NEngl J Med 2015; 372: 134-141

Nie istnieje jeden standard leczenia chorych na raka piersi z małym guzem i bez zajętych węzłów chłonnych, z obecnością receptora HER2, ponieważ większość takich chorych nie kwalifikowała się do udziału w badaniach klinicznych oceniających uzupełniające leczenie trastuzumabem.

Metody. Przeprowadzono wieloośrodkowe niekontrolowane badanie kliniczne z jedną grupą chorych. Do badania z uzupełniającym leczeniem paklitakselem z trastuzumabem włączono 406 chorych z guzami o średnicy $<3 \mathrm{~cm}$. Chore otrzymywały co tydzień paklitaksel z trastuzumabem przez 12 tygodni, a następnie trastuzumab przez 9 miesięcy. Głównym punktem końcowej oceny był czas wolny od choroby inwazyjnej.

Wyniki. Mediana czasu obserwacji wyniosła 4 lata. Udział 3-letnich przeżyć wolnych od naciekającego raka wyniósł 98,7\% (95\% przedział ufności [Cl] 97,6 do 99,8). Wśród 12 nawrotów 2 obejmowały rozsiew choroby. Po wykluczeniu HER2-ujemnych raków drugiej piersi oraz nowotworów innych niż rak piersi stwierdzono 7 zdarzeń związanych z chorobą. 13 chorych $(3,2 \% ; 95 \% \mathrm{Cl} 1,7$ do 5,4$)$ podało przynajmniej jeden epizod neuropatii 3. stopnia, a u dwóch wystąpiła objawowa niewydolność krążenia $(0,5 \% ; 95 \% \mathrm{Cl}$ 0,1 do 1,8); w obu przypadkach po odstawieniu trastuzumabu frakcja wyrzutowa lewej komory wróciła do normy. U 13 chorych doszło do bezobjawowego obniżenia frakcji wyrzutowej (3,2\%; 95\% Cl 1,7 do 5,4), ale u 11 z nich po krótkiej przerwie możliwa była kontynuacja leczenia trastuzumabem.

Wnioski. Wśród chorych na raka piersi w I stopniu zaawansowania z obecnością receptora HER2 uzupełniające leczenie paklitakselem i trastuzumabem wiązało się z ryzykiem wczesnego nawrotu. Około 2\%; 6\% chorych wyłączono z badania z powodu działań niepożądanych związanych z protokołem.

\section{Carfilzomib, lenalidomide, and dexamethasone for relapsed multiple myeloma}

Stewart AK, Rajkumar SV, Dimopoulos MA i wsp.

N Engl J Med 2015; 372: 142-152

Lenalidomid w połączeniu z deksametazonem jest leczeniem z wyboru chorych na nawrotowego szpiczaka mnogiego. Połączenie inhibitora proteasomu karfilzomibu z lenalidomidem i deksametazonem było skuteczne w leczeniu nawrotu szpiczaka mnogiego w badaniach I i ll fazy.

Metody. 792 chorych z nawrotem szpiczaka mnogiego przydzielono losowo do leczenia karfilzomibem z lenalidomidem i deksametazonem lub lenalidomidem z deksametazonem (grupa kontrolna). Głównym punktem końcowej oceny był czas do progresji.

Wnioski. Czas do progresji był znamiennie dłuższy w grupie leczonej karfilzomibem (mediana 26,3 miesiąca w porównaniu z 17,6 miesiąca w grupie kontrolnej; współczynnik ryzyka progresji lub zgonu 0,69; 95\% przedział ufności [CI] 0,57 do $0,83 ; p=0,0001)$. Mediana całkowitego czasu przeżycia nie została osiągnięta w żadnej z grup w czasie planowej analizy 
w trakcie badania. Udział 24-miesięcznych całkowitych przeżyć w grupie leczonej karfilzomibem oraz w grupie kontrolnej wyniósł odpowiednio 73,3\% oraz 65,0\% (współczynnik ryzyka zgonu 0,79; $95 \% \mathrm{Cl} 0,63$ do 0,99; $\mathrm{p}=0,04$ ). Udziały odpowiedzi (częściowych lub lepszych) w grupie leczonej karfilzomibem i w grupie kontrolnej wyniosły odpowiednio $87,1 \%$ i $66,7 \%$ ( $p<0,001$; odpowiednio $31,8 \%$ i $9,3 \%$ wśród chorych z odpowiedzią całkowitą lub lepszą; 14,1\% i 4,3\% z bezwzględną odpowiedzią całkowitą). Działania niepożądane 3. lub wyższego stopnia w grupie leczonej karfilzomibem i w grupie kontrolnej wystąpiły odpowiednio u $83,7 \%$ i $80,7 \%$ chorych, a $15,3 \%$ i $17,7 \%$ chorych w obu grupach zakończyło leczenie z powodu działań niepożądanych. Jakość życia związana ze zdrowiem była lepsza w grupie leczonej karfilzomibem.

Wnioski. Dołączenie karfilzomibu do lenalidomidu z deksametazonem znamiennie wydłużyło czas do progresji chorych na nawrotowego szpiczaka mnogiego w analizie przeprowadzonej w trakcie badania przy korzystnym profilu toksyczności.

\section{Improved overall survival in melanoma with combined dabrafenib and trametinib \\ Robert C, Karaszewska B, Schachter J i wsp. \\ NEngl J Med 2015; 372: 30-39}

Inhibitory BRAF wemurafenib i dabrafenib są skuteczne w monoterapii u chorych na nieleczonego rozsianego czerniaka z mutacjami BRAFV600E lub V600K. Połączenie dabrafenibu i inhibitora MEK trametynibu zwiększało aktywność przeciwnowotworową w tej grupie chorych w porównaniu z leczeniem wyłącznie dabrafenibem.

Metody. W otwartym badaniu III fazy 704 chorych na rozsianego czerniaka z mutacją BRAF V600 przydzielono losowo do leczenia dabrafenibem (150 mg $2 \times$ dziennie) i trametynibem ( $2 \mathrm{mg}$ raz dziennie) lub wemurafenibem (960 mg $2 \times$ dziennie) doustnie w pierwszej linii leczenia. Głównym punktem końcowej oceny był czas całkowitego przeżycia. Wyniki. We wcześniej zaplanowanej analizie czasu całkowitego przeżycia, przeprowadzonej w trakcie badania po wystąpieniu 77\% przewidywanych zdarzeń, udział całkowitych przeżyć po 12 miesiącach wyniósł 72\% (95\% przedział ufności [CI] 67 do 77\%) w grupie leczonej w sposób skojarzony oraz $65 \%$ (95\% Cl 59 do 70\%) w grupie leczonej wemurafenibem (współczynnik ryzyka zgonu w grupie leczonej w sposób skojarzony 0,69; $95 \% \mathrm{Cl}$ 0,53 do 0,89; $p=0,005)$. Przekroczono ustaloną granicę potwierdzającą skuteczność i w lipcu 2014 roku badanie przerwano. Mediana czasu do progresji wyniosła 11,4 miesiąca w grupie leczonej w sposób skojarzony oraz 7,3 miesiąca wśród leczonych wemurafenibem (współczynnik ryzyka 0,56; 95\% $\mathrm{Cl} 0,46$ do 0,69; $\mathrm{p}<0,001$ ). Udział całkowitych odpowiedzi wyniósł $64 \%$ wśród leczonych w sposób skojarzony oraz $51 \%$ w grupie leczonej wemurafenibem $(p<0,001)$. Udział ciężkich działań niepożądanych oraz zaniechanie dalszego leczenia były podobne w obu grupach. Płaskonabłonkowe raki skóry i rogowiaki kolczystokomórkowe wystąpiły u 1\% chorych leczonych w sposób skojarzony i u 18\% wśród leczonych wemurafenibem.

Wnioski. Dabrafenib w połączeniu z trametynibem znamiennie wydłużał czas całkowitego przeżycia nieleczonych chorych na rozsianego czerniaka z mutacjami BRAF V600E lub V600K bez zwiększonej toksyczności w porównaniu z leczeniem wemurafenibem.

Opracowali:

Dr n. med. Anna Kowalczyk

Dr n. med. Ewa Szutowicz-Zielińska

Lek. med. Anna Wrona

Dr n. med. Krzysztof Konopa 